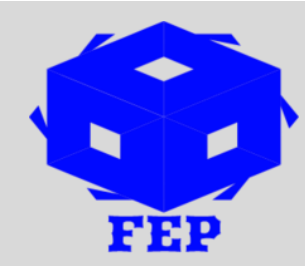

\title{
IMPORTANCE OF FINANCIAL TECHNOLOGY IMPLICATIONS FOR PROFESSIONALS IN INDONESIA
}

\author{
Hamza Alshenqeeti ${ }^{1}$, Rita Inderawati ${ }^{2}$ \\ 1,2 Andalas University, Padang, Indonesia
}

*Corresponding Author: Hamza Alshenqeeti

Article Received: 08-10-19

Accepted: $14-01-20$

Published: 05-02-20

Licensing Details: Author retains the right of this article. The article is distributed under the terms of the Creative Commons Attribution-Non Commercial 4.0 License (http://www.creativecommons.org/licences/by-nc/4.0/) which permits non-commercial use, reproduction and distribution of the work without further permission provided the original work is attributed as specified on the Journal open access page.

\begin{abstract}
The focus of the study was to test the financial technology for professionals and its influence on the financial system. The study notes that those professionals who fails to align with the ever-changing technology will not be able to survive their field. Therefore, it is recommended that professionals must be proactive to use financial technology. Furthermore, the regulators in particular field must be technologically inclined with regard to financial technology. Based on regulators pressure and personal motivation, the professionals and firms must take efforts to develop workers for financial technology such as data protections of customers. The government can also develop policies to boost financial technology in Indonesia.
\end{abstract}

Keywords: Financial Technology, Professionals, Innovation, Financial Services, Indonesia

\section{INTRODUCTION}

FinTech refers to the financial technology. The financial system across the world plays central role in ensuring sustained and comprehensive growth. There are many changes occurring in every field and financial system is not exception. There is trend of digitalization and use of technology in the financial field. These new technologies referred to as 'fintech' (Truong, 2016). The outcome of Fintech is that it has filled several of the financial system gaps and several new solutions have been preferred to problems with the introduction of channels such as Bitcoin digital currency and the PayPal (Gonzalez, 2004). A report by World Fintech (2018) states that Fintech has a synergetic relationship with the traditional 
financial system in terms of improving infrastructure, customer trust, and customer loyalty. Furthermore, the outcome of Fintech is that it has leveraged gaps which were not fulfilled by previous financial structure such as increased access to customers using the mobile and online channels. One example is Airbnb introduced by Slice labs in the insurance industry which provides insurance platform coverage for customers for only the duration of their stay in a particular area.

Fintech is truly revolutionizing since it has changed many aspects of financial system along with the regulatory framework and rise of automatic channels within the system.

Gelis and Woods (2014) states that Fintech has its origin in London which is considered as undisputed Fintech capital. Even though, there is a large Fintech hub in California and also there are some channels present in other places including China using channels such as Alibaba and Alipay. However, in country like Indonesia, Fintech is just finding it foots. According to PWC (2017) only one third of the clients of businesses in Indonesia makes use of mobile applications and only one fifth of clients use it once per month. In other words, we can say that Fintech is not well established in Indonesia.

In literature, there is mixed response from scholars regarding the influence of Fintech. Some considered it positive, while, other considered it negatively (Akhisar, Tunay, and Tunay, 2015). Fintech is considered to be influencing every country but country like Indonesia, it is weak. The professionals in Indonesia also provided mixed response regarding the introduction of the Fintech. In this study, we investigate the Fintech use and perception towards it by professionals in Indonesia.

\section{LITERATURE REVIEW}

\section{The Concept of Fintech}

Fintech refers to firms which provide financial services using the sound technology platform in a bid to invent new financial products and services which can be reached by wider audience. According to Truong (2016), the increased use of Fintech is that firms are finding new ways to provide financial services such as asset management or money transfer. The benefit of Fintech is that it provide low cost transactions and keep efficiency at the same time. It can also be seen as technologically enabled innovation within the financial system which leads to the formation of new business models, new products, and services (IAIS, 2017). Examples of such services include crowdfunding. Table 1 provide some of the list of financial technology services. 
Table 1

Sectors of Innovative Services

\begin{tabular}{|c|c|c|c|c|}
\hline \multicolumn{5}{|c|}{ Sectoral Innovations } \\
\hline \multirow{5}{*}{$\begin{array}{l}\text { Financial } \\
\text { Support } \\
\text { Services }\end{array}$} & $\begin{array}{l}\text { Credit, deposit, } \\
\text { capital-raising services }\end{array}$ & \multicolumn{2}{|c|}{ andPayments, Clearing and Settlement Services } & \multirow{2}{*}{$\begin{array}{l}\text { Investment Management } \\
\text { Services } \\
\text { High-Frequency Trading }\end{array}$} \\
\hline & Crowdfunding & Retail & Wholesale & \\
\hline & Lending Marketplaces & Mobile Wallets & $\begin{array}{l}\text { Value } \\
\text { Networks }\end{array}$ & TransferCopy Trading \\
\hline & Mobile Banks & $\begin{array}{l}\text { Peer-to-Peer } \\
\text { Transfers }\end{array}$ & FX Wholesale & E-Trading \\
\hline & Credit Scoring & Digital Currencies & $\begin{array}{l}\text { Digital Exchange } \\
\text { Platforms }\end{array}$ & Robo-Advices \\
\hline Market & \multicolumn{4}{|l|}{ SupportPortal and data aggregators } \\
\hline \multirow[t]{7}{*}{ Services } & \multicolumn{4}{|c|}{ Ecosystems (Infrastructure, Open source, APIs) } \\
\hline & \multicolumn{4}{|c|}{ Data applications (big data analysis, machine learning, predictive modeling) } \\
\hline & \multicolumn{4}{|c|}{ Distributed Ledger Technology (Blockchain, smart contracts) } \\
\hline & \multicolumn{4}{|c|}{ Security (Customer Identification and Authentication) } \\
\hline & \multicolumn{4}{|l|}{ Cloud Computing } \\
\hline & \multicolumn{4}{|c|}{ Internet of things / Mobile Technology } \\
\hline & \multicolumn{4}{|c|}{ Artificial Intelligence (bots, automation in finance, algorithms) } \\
\hline
\end{tabular}

\section{Benefits and Challenges of FinTech}

The Fintech at one hand bring advantages and on the other hand, it bring challenges. One big advantage of the Fintech is the expectations and behavioral preferences of customers as they embrace these changes in technology in a bid to operate comfortably for the financial system. Fintech is increasing because of greater demand for customization and personalization from the customers. The result is that more people can use financial services now. The latest Fintech system is flexible and versatile and can be used easily by the customers.

As far as the challenges of Fintech are concerned, so it includes lack of developed business model, limited compliance knowledge and absence of customer base and large capital. Many customers are loyal to their institutions and hesitant to adopt new Fintech since new innovation is taken with suspicion. Many organizations which could adopt the Fintech did not adopt it because of fear of losing all the investments since it requires bringing change in their business models. Also, a major challenge is bridging the cultural and behavioural gap that will exist between the traditional and new mode of operations as large money will be spent on orientation while some old customers may tend to leave.

\section{FinTech and Professional Services Providers}

Fintech operates in financial markets and it has greater influence on the financial professionals. The professionals include asset management firms, accounting firms, banking system, and insurance companies. The outcome of fast growing Fintech is that it requires professionals to be technologically adept and highly flexible while catching up with the 
changes in the environment. Examples of some of the challenges to financial institutions such as banks include compliance risk, data protection, money laundering, and financial risk (BCBS, 2018). The situation requires that managerial staff at banks must be alert and technologically inlined to ensure safe banking practices are followed.

\section{Global Trend of FinTech}

All over the word, Fintech is gaining ground in countries around the world. However, closer analysis indicate that Fintech has gained more popularity in developed countries compare to the developing countries. It is particularly popular in advanced countries such as UK, USA, and Canada; while, in developing countries such as Indonesia, it is still struggling to gain foothold. In developed countries, it is used for various services such as crowdfunding, wealth management, payment, exchange, business management, and insurance. It resulted in development of innovation hubs and labs for Fintech association with emphasis on P2P lending. In countries like China, it has gained so much popularity that it has come close to competition with big players such as New York and London. The rise of Fintech in China is based on the pro-Fintech policies by the government. The result is firms like Tencent, Alibaba, and Baidu. The global Fintech statistics are provided below.

Table 2

\begin{tabular}{cc} 
Global Most Used FinTech Services \\
\cline { 2 - 2 } Transfers and Payments & $60 \%$ \\
Insurance & $24 \%$ \\
Savings and Investments & $20 \%$ \\
Borrowing & $20 \%$ \\
Financial Planning & $20 \%$ \\
\hline
\end{tabular}

Table 3

\begin{tabular}{cc} 
Global FinTech Adoption across Age Brackets \\
\cline { 2 - 2 } $18-23$ & $37 \%$ \\
$25-33$ & $58 \%$ \\
$35-33$ & $33 \%$ \\
$35-53$ & $30 \%$ \\
$55-63$ & $22 \%$ \\
$65-75$ & $17 \%$ \\
$75+$ & $7 \%$
\end{tabular}


Table 4

\begin{tabular}{lc} 
Global FinTech Adoption across Markets \\
\cline { 2 - 2 } China & $58 \%$ \\
India & $24 \%$ \\
United Kingdom & $22 \%$ \\
Brazil & $40 \%$ \\
Australia & $27 \%$ \\
Spain & $27 \%$ \\
Mexico & $28 \%$ \\
Germany & $25 \%$ \\
South Africa & $25 \%$ \\
United States of America & $22 \%$ \\
\hline
\end{tabular}

\section{Application of FinTech to the Advancement of Financial Services}

In financial system, the Fintech which is about incorporation of technology in to the financial system has a lot to do with services rendered. The rise of Fintech is giving rise to competition and greater choices; while, Fintech firms have fewer regulations to comply with. For making financial services available to large number of individuals, Fintech is improving and making financial inclusion a reality by reaching places physical distribution cannot reach such as mobile networks. Moreover, Fintech takes the focus of services completely away from the source of supply to the customer, his access, convenience, and comfort. The outcome of such customer oriented approach is that provision of financial services are likely to take a quantum leap.

\section{Lag in the Non-Application of FinTech}

Policy lag in economics term refers to the length of time which occurs between when a policy is made, implemented, and its effects can be observed in an economy. In this particular situation, lag is the gaps which is created within the financial system and may be translating to serious issues in the economy at large as a result the inability to incorporate Fintech in a particular financial system. South East Asian countries such as Indonesia lags behind when it comes to financial framework, structure, and environment. Even though, there are some Fintech channels exist in Indonesia such as black chain technology and mobile money but the result of its shallow implementation in Indonesia have opened up some gaps in the financial system. One major issue is the achievement of Fintech channels in Indonesia and making it a reality. The other challenge is that there is lack of inclusion as the 
services are not reached to every individuals in the society. Another challenge is that the Fintech system is in the hand of few who are outside the control of the financial system. One more lag is the inability of financial system in Indonesia to interact with rest of the world mainly because of few problems such as language barrier.

\section{THEORETICAL LITERATURE}

Below we present some of the theories related to the Fintech are discussed below.

\section{Theory of Dynamic Capabilities}

According to Teece, Pisano, and Shuen (1997), dynamic capability focuses on firm specific factors such as complementary assets and knowledge which shapes a firm's competitive advantage. The result is that from firms point of view, these firms want to develop dynamic capabilities in order to enhance the performance of businesses in the long term. This development of dynamic capabilities involves developing human resource in order to support the changing requirements occurring in a firm's environment. According to Leonard-Barton (1992), the ability to develop new innovative firms for competitive advantage is the premise whereon dynamic capabilities is developed.

\section{Theory of Organizational Learning}

According to the organizational learning theory, for developing dynamic capabilities, information must be provided to the entire organization for ensuring an orientation and crossfunctional utilization of such technologies. Ford (1988) suggest that the external acquisition of collaboration through inter-organizational collaboration mechanism is crucial for a firm's strategy of technology. For efforts related to the development of new things, organizations may fail in several attempts but must learn through such processes as such firms are likely to underestimate failures and oversample success (Levinthal \& March, 1993).

\section{Innovator's Solution Theory}

According to Christensen and Taylor (1997), innovator's solution theory provide explanation about why a firm fail to innovate. The major tenant of this theory is that big organizations are not so oriented to tackle the problem of disruptive innovation as such disruptive ideas may serve as a threat to management, corporate culture, and power structure. The outcome of such situation is that existing forces resist innovation which can be in the form of fintech. The proponent of the theory also states that managers in a firm should establish a wall between the oncoming innovation and the prevailing hierarchy and structure. Accordingly, independent business unit can be established to provide a safe environment for innovation (Kariuki, 2010). 


\section{Disruptive Innovation Theory}

Christensen (1997) proposed the disruptive innovation theory which assumes that innovation can be used as a competitive advantage by an organization. The outcome of innovation is that it may creates some uncertainty for market but author argues that as the radical type of innovation occurs, it is difficult to easily conclude on its market acceptance. Disruption innovation bring improvement in a company's growth and lay foundation for new market trends.

\section{CONCLUSION AND RECOMMENDATIONS}

The aim of the study was to theoretically and conceptually examine the fintech implications for professionals in the financial system in the Indonesian context. Our analysis indicate that in the $21^{\text {st }}$ century globalized world, professionals need to continuously improve their knowledge about the latest technology including Fintech, otherwise, their employment and survival can be at risk. Based on the study, we recommend that financial professionals must take deliberate efforts to technologically educate themselves. Furthermore, the regulators must be technologically adept in a bid to curb excesses which may arise as a result of the rise of Fintech such as non-compliance with data protection of customers while firms must regularly develop its staff and build dynamic capabilities to ensure that firms adopt to the dynamic nature of Fintech within the financial system. Finally, government in Indonesia need to develop such policies which improve the Fintech use and implementation in the country.

\section{References}

Abaenewe, Z. C., Ogbulu, O. M., \& Ndugbu, M. O. (2013). Electronic Banking and Bank Performance. West African Journal of Industrial and Academic Research, 6(1), 171187.

Akhisar, I., Tunay, K. B., \& Tunay, N. (2015). The Effects of Innovations on Bank Performance: The Case of Electronic Banking Services. Procedia-Social and Behavioural Sciences, 195(2015), 369-375.

Amer, D. W., Barberis, J. N., \& Ross, P. (2015). The Evolution of Fintech: A New Post Crisis Paradigm? University of Hong King Faculty of Law Research Paper Series.

BCBS. (2018). Implications of Fintech developments for banks and bank supervisors. BIS Paper Series.

Bergara, M., \& Ponce, J. (n.d). How Disruptive are FinTechs? Unpublished Paper, 1-22.

Christensen, C. M. (2003). Examining Possible Antecedents of IT Impact on the Supply Chain and its Effect on Firm Performance. Information and Management, 41(2), 227241. 
Davis, K. (n.d). Fintech and its Regulation in Australia. Australian Centre for Financial Studies Research Paper Series.

Dezshira (2018). China's FinTech Industry. Retrieved from www.dezshira.com

Erman, C. (2017). Financial Technologies Effect on Financial Services from an Open Innovation Perspective. (M.Sc. Thesis). Lappeenranta University of Technology.

EY. (2017). FinTech Adoption Index 2017: Key Findings.

Retrieved from

http://www.ey.com/Publication/vwLUAssets/ey-fintech-key-findings-2017/\$FILE/ey-

fintechkey-findings-2017.pdf

Gelis, P., \& Woods, T. (2014). The Rise of Fintech in Finance. Kantox Paper Series, 1(1), 112.

Gonzalez, A. G. (2004). PayPal: The Legal Status of the c2c Payment Systems. Computer Law and Security Review, 20(7), 293-299.

IAIS (2017). FinTech Developments in the Insurance Industry. IAIS Paper Series, 1(1), 1-46.

Kariuki, F. W. (2010). The Relationship between Financial Engineering and Financial Performance of Commercial Banks in Kenya. (M.BA Thesis). University of Nairobi.

Leonard-Barton, D. (1992). Core Capabilities and Core Rigidities: A Paradox in Managing New Product Development. Strategic Management Journal, 13(1), 111-125.

Levinthal, D. A., \& March, J. G. (1993). The Myopia of Learning. Strategic Management Journal, 14(2), 95-112.

Steensma, H. K. (1996). Acquiring Technological Competencies through InterOrganizational Collaboration: An Organizational Learning Perspective. Journal of Engineering and Technology Management, 12(4), 319-330.

Teece, D. J., Pisano, G., \& Shuen, A. (1997). Dynamic Capabilities and Strategic Management. Strategic Management Journal, 1(1), 509-533.

Truong, O. (2016). How Fintech Industry is Changing the World. (B.Sc. Thesis). Centria University of Applied Sciences. 